\title{
A Rare Case of Vertebral Osteomyelitis Developing After Enterococcal Bacteremia in a Geriatric Patient
}

\section{Geriatrik Bir Hastada Enterokokal Bakteriyemi Sonrasında Gelișen Nadir Bir Vertebral Osteomiyelit Olgusu}

\author{
Asım ÜLÇAY' ${ }^{1}$, Ergenekon KARAGÖZ1', Serkan ARIBAL ${ }^{2}$, Vedat TURHAN¹, Seçkin SARI ${ }^{3}$, Selim AKARSU4 \\ 'Department of Infectious Diseases and Clinical Microbiology, Gülhane Military Medical Academy Haydarpaşa Training Hospital, Istanbul, Turkey \\ ${ }^{2}$ Department of Radiology, Gülhane Military Medical Academy Haydarpaşa Training Hospital, Istanbul, Turkey \\ ${ }^{3}$ Department of Orthapedic Surgery, Baltalimanı Orthapedic Training and Research Hospital, Istanbul, Turkey \\ ${ }^{4}$ Department of Physical Medicine and Rehabilitation, Gülhane Military Medical Academy Haydarpaşa Training Hospital, Istanbul, Turkey
}

\begin{abstract}
Vertebral osteomyelitis and discitis are rare entities. Although enterococci are a major cause of bacteremia and infective endocarditis, hematogenous enterococcal vertebral osteomyelitis has rarely been reported. In this article, a geriatric case is presented who had visited our hospital with complaints of "distorting back pain" and weakness in the legs and who had been diagnosed with vertebral osteomyelitis caused by enterococcus faecalis. In this case, the lesion of the patient was not distinguished from the metastasis with imaging studies, and the definitive diagnosis was confirmed by open tissue biopsy. As a result, bacteremic patients with back pain must be considered for vertebral osteomyelitis/discitis. Although imaging with MRI or a tissue biopsy will be helpful to confirm the diagnosis, open tissue biopsy and bone biopsy are more effective and crucial options for making a definitive diagnosis in some cases.

Key Words: Vertebral osteomyelitis, spondylodiscitis, Enterococcus faecalis
\end{abstract}

Özet

Vertebra osteomiyeliti ve diskiti nadir görülen bir hastalıktır. Enterokoklar bakteriyemi ve infektif endokarditlerin majör nedenleri arasında yer alsalar $\mathrm{da}$, hematojen yayılımlı enterokokal vertebral osteomiyelit olguları çok az sayıda rapor edilmiştir. Bu yazıda, şiddetli bel ağrısı ve ayaklarda güçsüzlük yakınmaları ile hastanemize başvuran ve Enterococcus faecalis'in neden olduğu vertebral osteomiyelit tanısı alan geriatrik bir olgu sunulmaktadır. Olgumuzda, hastamızın belindeki lezyon görüntüleme yöntemleri ile metastaz ve malignitelerden ayırt edilememiş ve kesin tanı açık doku biyopsi işlemi ile konmuştur. Sonuç olarak; bel ağrısı yakınması olan bakteriyemik hastaların ayırıcı tanıları arasında vertebral osteomiyelit bulunmalıdır. Manyetik rezonans görüntüleme (MRG) ya da doku biyopsileri tanı için yardımcı olsalar da, açık doku biyopsi ve kemik biyopsileri bazı olguların tanısında daha etkili ve önemli seçeneklerdir.

Anahtar Kelimeler: Vertebral osteomiyelit, spondilodiskit, Enterococcus faecalis

\section{Introduction}

There is a predisposition to osteomyelitis in the adult population. This is due to one of many reasons, such as a higher incidence of associated disorders (peripheral vascular disease, diabetes mellitus, malnutrition and poor dentition, immunosuppressive therapies). Additionally, invasive techniques, like endo- scopic interventions, dental extractions, open heart surgery, and prosthetic joint replacement or osteosynthesis, that are often performed in the elderly population may contribute to their increased risk (1-3).

Infectious spondylodiscitis has been diagnosed with increasing frequency (4). This reflects the expanding elderly and immu-

Address for Correspondence / Yazışma Adresi: Ergenekon Karagöz, MD, Department of Infectious Diseases and Clinical Microbiology, Gülhane Military Medical Academy Haydarpaşa Training Hospital, İstanbul, Turkey. Phone: +90 2165422020 E-mail: ergenekonkaragoz@hotmail.com

Received/Geliş Tarihi: August/Ağustos 2013 Accepted/Kabul Tarihi: November/Kasım 2013 
nocompromised populations, as well as the increasing use of invasive spinal procedures and enhanced ascertainment due to the greater availability of $\mathrm{MRI}$, the most sensitive method for radiological diagnosis $(4,5)$. However, hematogenous vertebral osteomyelitis and discitis are rarely seen.

Herein, we present a vertebral osteomyelitis case that was cured only by antibiotherapy and was caused by a rare agent, Enterococcus faecalis, in a geriatric male patient having had a malignancy experience and lumbar disc hernia operation 10 years ago.

\section{Case Report}

A 74-year-old man was admitted to our hospital with back pain and weakness in his legs in May 2012. In his history, he had been operated on because of a lumbar disc hernia and bladder cancer 10 years ago, but the weakness in his legs, which he complained about from that date, had not improved. Three years ago, he visited a neurosurgery polyclinic, and the doctors told him that he had to be operated on again because of his lumbar disc hernia, but he refused the operation. When his back pain increased, he was admitted to the department of physical therapy and rehabilitation and hospitalized 2 months ago. After his pain was minimally reduced by analgesics, he was discharged. Because of his persistent back pain, he visited our hospital again and was hospitalized in the Department of Infectious Disease. The admission vitals of the patient were normal, except for a body temperature of $37.8^{\circ} \mathrm{C}$. The patient had weakness and numbness in both of his legs. The patient was uncooperative in the neurological exam due to his distorting back pain. In the laboratory, his white blood cell count was 11,000 cells $/ \mathrm{mL}$, erythrocyte sedimentation rate was $100 \mathrm{~mm} / \mathrm{h}$, and C-reactive protein was $84 \mathrm{mg} / \mathrm{L}$ (0-8 mg/L). An X-ray of the thoracolumbar spine demonstrated degenerative joint disease (DJD), including T10-11. Magnetic resonance imaging (MRI) was performed to demonstrate the pathology and to perform a further evaluation. The findings on his initial MRI were compatible with spondylodiscitis at the level of T10-11 (Figure 1a, b). Blood cultures were positive for Enterococcus faecalis in four sets of blood culture bottles, and this microorganism was susceptible to ampicillin, ciprofloxacin, and other antibiotics. After this result, we commenced treatment with daptomycin $500 \mathrm{mg}$ once a day and ciprofloxacin $400 \mathrm{mg}$ twice a day due to the systemic infection findings and the severe clinical course of the patient. Urine analyses and cultures were negative. Transthoracic echocardiography did not reveal valvular vegetation that showed infective endocarditis. In addition, due to the bladder cancer history, he had been visiting the urology service for a cystoscopic examination every year. Ten days after initiating the treatment, daptomycin and ciprofloxacin were stopped and altered with a broad-spectrum antibiotic, $500 \mathrm{mg}$ of imipenem, administered every 6 hours, due to the fear of undetected, persevering bacteremia. After 1-month antibiotic treatment, the patient's pain decreased, and a control MRI was performed. Compared to the first MRI, the lesion had progressed (Figure 2a). Therefore, PET/CT was done for further observation to evaluate the lesion on the T10-11 level. It was observed that there was an inflammatory lesion at the right sac-
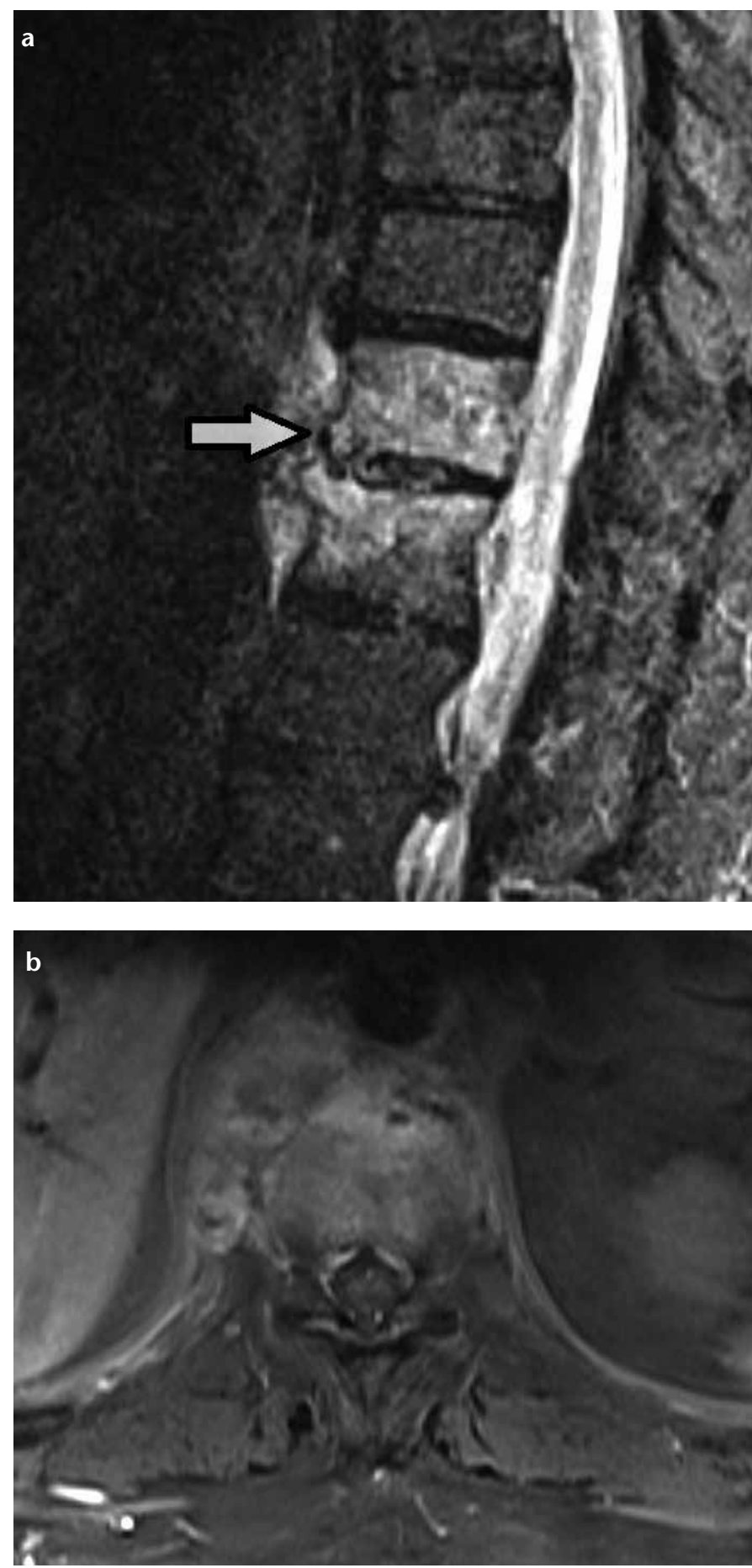

Figure 1. a, b. MRI images before the treatment. High signal intensity was seen through the bodies of the thoracic (T)10 and 11 vertebrae in the sagittal STIR image, which is pathological and indicates bone marrow edema and inflammation. High signal intensity was also seen in the prevertebral soft tissue. Note that the lower part of the T 11 vertebral body is not affected (white arrow) (a). Post-contrast axial fat-saturated T1W images show heterogeneous contrast fixation through the vertebral bodies and the pre-paravertebral soft tissues (b). 


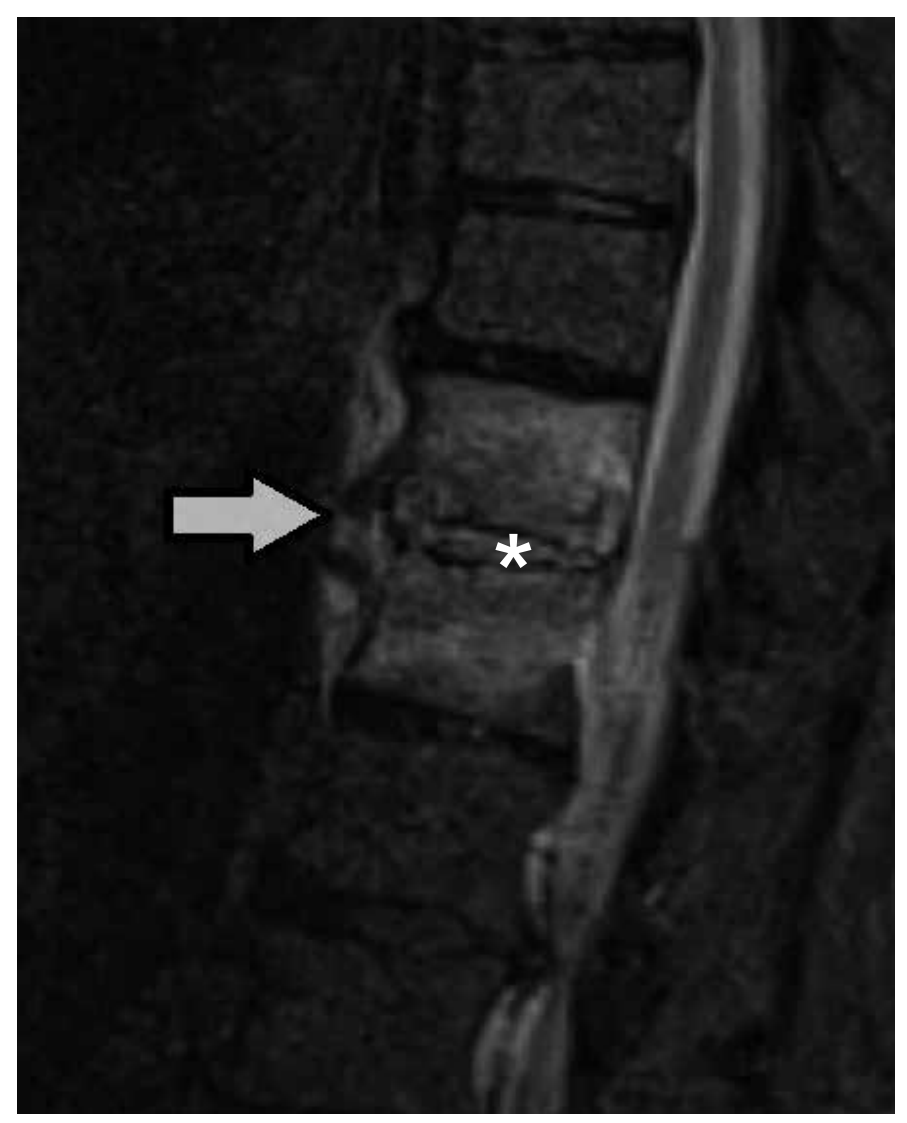

Figure 2. The first control MRI images after 1-month treatment. Sagittal STIR image: we again see high signal intensity through the vertebral bodies. But, compared to the baseline MRI (Figure $1 \mathrm{a})$, the signal at the level of the lower part of the T11 vertebral body (white arrow) and the intervertebral disk space (asterisks) between T10 and 11 are new findings and indicate progression

roiliac joint, the bone activity had increased, and it could not be determined whether there was bone metastasis or not.

The patient was discussed in the council of consultation at our hospital (orthopedics, neurology, neurosurgery, internal medicine, oncology, urology, interventional radiology, nuclear medicine, ID physicians), and it was concluded that the lesion might be compatible with either metastasis of genitourinary cancer or spondylodiscitis. They decided to make surgical samples from the lesion at the T10-11 level, allowing them to conduct further tests and observations. But, before sampling, oncological and urological consultations were completed for the patient. Cystoscopy was done by urologists, and after the urological examination, they declared that there were no tumors in either the prostate or bladder. After the urological and oncological examinations, to confirm the definite diagnosis, fine needle aspiration and then tissue sampling were accomplished by open surgical biopsy of the bone lesion; the sampling results were consistent with 'chronic osteomyelitis.' Specific and non-specific cultures were taken from the surgical biopsy specimen in the bone lesion, and they were found to be negative for both tuberculosis

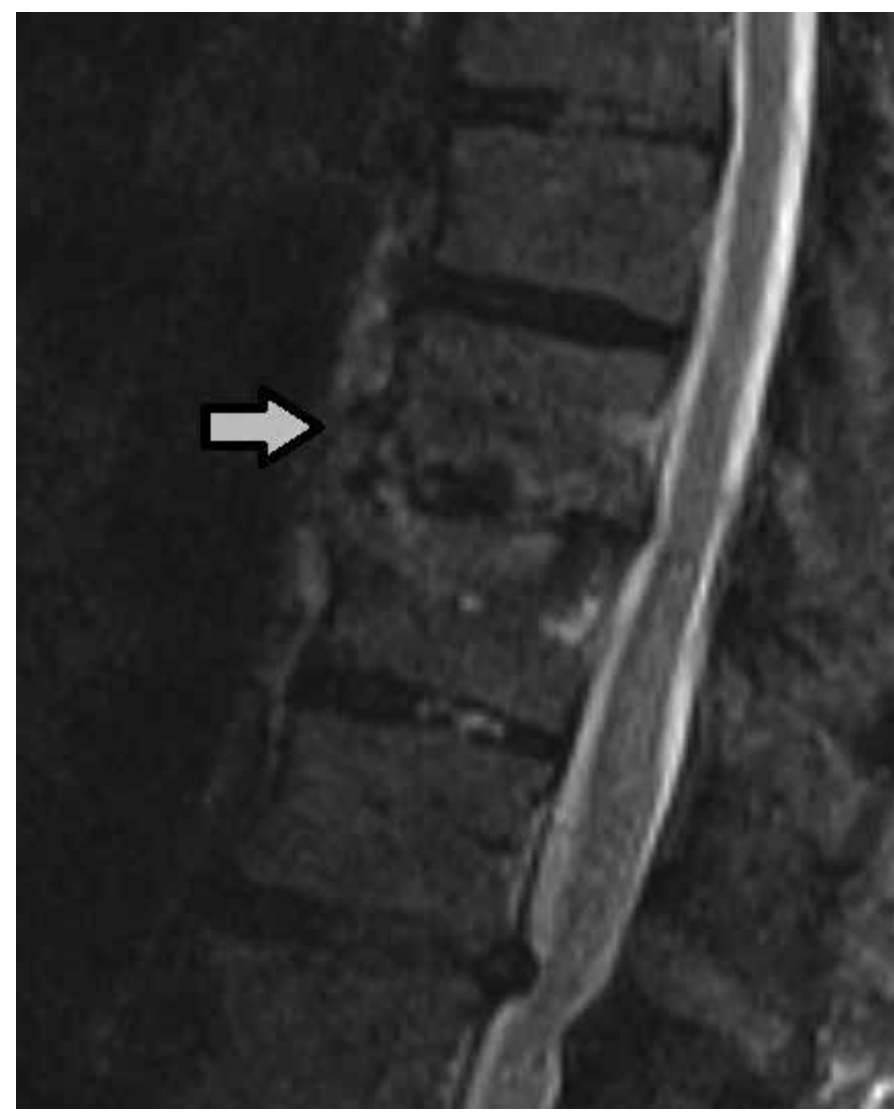

Figure 3. The second control MRI images after the treatment. Sagittal STIR image: compared to the first control MRI, the high signal intensity through the vertebral bodies and intervertebral disk space regressed almost completely. The intervertebral disk space narrowed slightly, and the end plates adjacent to the intervertebral disk space were irregular and locally destroyed

and non-specific bacteria, including enterococci. Tests for tuberculosis (acid-fast bacilli staining, culture, and PCR), brucellosis (Rose Bengal and Wright agglutination tube tests), and salmonellosis (Gruber-Widal agglutination test) were negative. After 1 month of intravenous antibiotherapy, the patient was released from the hospital on $1 \mathrm{~g}$ of amoxicillin (bid, per oral) and 500 mg of ciprofloxacin (bid, per oral). Follow-up visits in the infectious diseases department were scheduled. After an extended period of rehabilitation and physical therapy, the patient recovered completely.

After the 3 months of antibiotic treatment, the physical examination and laboratory tests of the patient were normal. In his second control MRI, the findings indicated regression (Figure 3). He has not had a relapse of his infection for 15 months.

\section{Discussion}

Infectious spondylodiscitis can be seen in the causative microorganisms that a single microorganism is generally involved, despite the occurrence of polymicrobial infections, particularly in the context of decubitus ulcers, chronic debility, and immunosuppres- 
sion $(4,6)$. Hadjipavlou et al. $(4,7)$ studied 101 patients with nonpostoperative pyogenic spinal infection. Seventy-six patients had positive cultures, of which $68 \%$ revealed a single organism, $21 \%$ revealed two organisms, and $11 \%$ had more than two organisms. Polymicrobial infections did not impact the outcome in this trial. Staphylococcus aureus is the most common organism isolated, being involved in $15 \%-84 \%$ of non-tuberculous patients $(4-6,8)$. This is followed in frequency by gram-negative bacilli (4\%-30\% of pyogenic cases) and streptococci/enterococci $(5 \%-30 \%)(4,5)$. Enterococci are the third most frequent bacterial agents in septic arthritis of prosthetic joints and are seen in native joint infections and diabetic foot osteomyelitis $(1,9)$.

Enterococci naturally inhabit the colon, oral cavity, vagina, female perineum, and anterior urethra of both men and women (1). It is an important pathogen in intra-abdominal, pelvic, and urinary tract infections $(1,10)$. To date, in all case reports, some of the common predisposing factors are male gender, diabetes, and age over 50 years $(1,9,11)$. Immunosuppression may be one of the other outstanding risk factors; the others are prior instrumentation of the gastrointestinal, genitourinary, or respiratory tract; hospitalization for more than 3 weeks; and use of broad-spectrum antibiotics, particularly cephalosporins with lower or no enterococcal activity (12).

In a study of 80 adult patients with pyogenic and tuberculous spondylodiscitis, diabetes mellitus was the most prominent risk factor, existing in $18 \%$ of patients $(1,11)$. One other risk factor for spondylodiscitis is infective endocarditis. Enterococci are usually the culprits in $5 \%$ to $20 \%$ of all infective endocarditis cases. It is typically associated with the use of intravascular devices and wounds and infections of the abdomen and urinary tract $(1,9)$.

Enterococci-related spondylodiscitis is uncommon, and only a few cases have been reported to date $(1,13)$. It is possible to witness hematogenous spread by arterial route to the vertebral bodies. Another role may be played by venous circulation: in the context of increased abdominal pressure, the transmission of sepsis from the pelvic organs is facilitated by retrograde flow from the pelvic venous plexus to the paravertebral plexus $(4,14)$. Acute backache and fever are the most frequent clinical findings of spondylodiscitis $(7,8)$. In a trial by Perronne et al. (11), 25 cases of pyogenic spondylodiscitis were evaluated, and in only 2 of the patients was E. faecalis the causative agent; the portal of entry of the causative agent in these 2 cases was found to be related to prostate resection and a pacemaker.

Another cause of bacteremia that resulted in disk space/vertebral seeding was the presence of multiple risk factors in our patient: his age (74 yrs), male gender, past medical history of diabetes, and prior instrumentation of the genitourinary tract. Also, in our case, although the pains of the patient decreased after 1-month antibiotic treatment, the lesion of the patient was imagined as progressing interestingly in the control MRI. In literature, we have seen that the radiologic findings in MRI may actually worsen while the patient is improving clinically $(4,15)$. MRI has limited value in assessing recovery, especially in the early phase of antibiotic treatment. Also, in the context of clinical improvement, persistent or increased gadolinium uptake does not necessarily denote treatment failure or deterioration $(4,16)$. Alternatively, for further diagnosis, a PET/CT was done, and we could not distinguish the lesion at the T10-11 level from metastasis, and we had to perform a tissue biopsy to confirm the diagnosis. Eventually, it was reported as chronic osteomyelitis.

Enterococcus faecalis has rarely been demonstrated to be the causative agent of hematogenous vertebral osteomyelitis (1). In this case, the lesion of the patient was not distinguished from the metastasis in the imaging studies, and the definite diagnosis was confirmed by open surgical biopsy of the bone lesion. The sampling results were consistent with chronic osteomyelitis. The specimen of the bone tissue biopsy was also examined in a microbiology laboratory, and the culture result was negative. A biopsy was able to be performed 1 month after initiating antibiotherapy, and for this reason, we are of the opinion that antibiotics might have suppressed the growth of the pathogenic microorganism.

\section{Conclusion}

Bacteremic patients with back pain must be considered for vertebral osteomyelitis/discitis. Although imaging with MRI or a tissue biopsy will be helpful to confirm the diagnosis, open tissue biopsy and bone biopsy are more effective and crucial options for making a definitive diagnosis in some cases.

Informed Consent: Written informed consent was obtained from patient who participated in this case.

Peer-review: Externally peer-reviewed.

Author Contributions: Concept - E.K.; Design - E.K., A.Ü.; Supervision - V.T.; Funding - E.K., V.T.; Materials - S.S.; Data Collection and/or Processing - E.K.; Analysis and/or Interpretation - E.K., S.A., S.S., S.Ak., V.T., A.Ü.; Literature Review - E.K.; Writer - E.K., A.Ü.; Critical Review - E.K., A.Ü., V.T.

Conflict of Interest: No conflict of interest was declared by the authors.

Financial Disclosure: The authors declared that this study has received no financial support.

Hasta Onamı: Yazılı hasta onamı bu olguya katılan hastadan alınmıştır.

Hakem değerlendirmesi: Dış bağımsız.

Yazar Katkıları: Fikir - E.K.; Tasarım - E.K., A.Ü.; Denetleme - V.T.; Kaynaklar - E.K., V.T.; Malzemeler - S.S.; Veri toplanması ve/veya işlemesi - E.K.; Analiz ve/veya yorum - E.K., S.A., S.S., S.Ak., V.T., A.Ü.; Literatür taraması - E.K.; Yazıyı yazan - E.K., A.Ü.; Eleştirel Inceleme - E.K., A.Ü., V.T.

Çıkar Çatışması: Yazarlar çıkar çatışması bildirmemişlerdir.

Finansal Destek: Yazarlar bu çalışma için finansal destek almadıklarını beyan etmişlerdir.

\section{References}

1. Punnaiah CM, Saquib H. Report of 2 cases of vertebral osteomyelitis/discitis caused by Enterococcus faecalis in dialysis patients. Infect Dis Clin Pract 2007;15:199-200. [CrossRef] 
2. Cunha BA. Osteomyelitis in elederly patients. Clin Infect Dis 2002;35:287-93. [CrossRef]

3. Romanò $\mathrm{CL}$, Logoluso $\mathrm{N}$, Elia $\mathrm{A}$, Romanò $\mathrm{D}$. Osteomyelitis in elderly patients. BMC Geriatrics 2010;10(Suppl 1):L15. [CrossRef]

4. Cottle L, Riordan T. Infectious spondylodiscitis. J Infect 2008;56:40112. [CrossRef]

5. Vergne P, Treves R. Infectious spondylodiscitis. Etiology, diagnosis, progression and treatment. Rev Prat 1998;48:2065-71.

6. Khan IA, Vaccaro AR, Zlotolow DA. Management of vertebral diskitis and osteomyelitis. Orthopedics 1999;22:758-65.

7. Hadjipavlou AG, Mader JT, Necessary JT, Muffoletto AJ. Hematogenous pyogenic spinal infections and their surgical management. Spine 2000;25:1668-79. [CrossRef]

8. Legrand E, Flipo RM, Guggenbuhl P, Masson C, Maillefert JF, Soubrier $M$, et al. Management of nontuberculous infectious discitis. treatments used in 110 patients admitted to 12 teaching hospitals in France. Joint Bone Spine 2001;68:504-9. [CrossRef]

9. Tarr PE, Sakoulas G, Ganesan A, Smith MA, Lucey DR. Hematogenous enterococcal vertebral osteomyelitis: report of 2 cases and review of the literature. J Infect 2004;48:354-62. [CrossRef]
10. Mandell GL, Bennett JE, Dolin R. Enterococcus Species, Streptococcus bovis Group and Leuconostoc Species, In: Arias CA, Murray BE., editors. Principles and Practice of Infectious Diseases. 7th ed. Elsevier, Philadelphia, USA, 2010.p.2643-54.

11. Perronne C, Saba J, Behloul Z, Salmon-Céron D, Leport C, Vildé JL, et al. Pyogenic and tuberculous spondylodiskitis (vertebral osteomyelitis) in 80 adult patients. Clin Infect Dis 1994;19:746-50. [CrossRef]

12. Harbarth S, Cosgrove S, Carmeli Y. Effects of antibiotics on nosocomial epidemiology of vancomycin-resistant enterococci. Antimicrob Agents Chemother 2002;46:1619-28. [CrossRef]

13. Zamora A, Florez J, Vidal F, Richart C. More on enterococcal osteoarticular infections: vertebral osteomyelitis. $\mathrm{Br}$ J Rheumatol 1997;36:1132-3. [CrossRef]

14. Govender S. Spinal infections. J Bone Joint Surg Br 2005;87:1454-8. [CrossRef]

15. Wirtz DC, Genius I, Wildberger JE, Adam G, Zilkens KW, Niethard FU. Diagnostic and therapeutic management of lumbar and thoracic spondylodiscitis--an evaluation of 59 cases. Arch Orthop Trauma Surg 2000;120:245-51. [CrossRef]

16. Varma R, Lander P, Assaf A. Imaging of pyogenic infectious spondylodiskitis. Radiol Clin North Am 2001;39:203-13. [CrossRef] 